\title{
Penerapan Wasiat Wajibah Dalam Putusan Penyelesaian Sengketa Waris Beda Agama Ditinjau Dari Perspektif Hukum Islam
}

\author{
Ahmad Baihaki \\ Fakultas Hukum, Universitas Bhayangkara Jakarta Raya \\ e-mail : baihaki.vision@gmail.com
}

Article info

Received: Apr 19, 2021 Revised: May 14, 2021 Accepted: May 22, $2021 \quad$ Published: Jun 10, 2021

DOI: https://doi.org/10.31599/krtha.v15i1.568

Keywords : inheritance legal, wajibah testament, Islamic Law

Abstract : The Islamic inheritance legal system normatively regulates that religious differences are one of the reasons for the barrier to inheriting inheritance between heirs and the decedent. However, in practice, the Religious Courts, the High Religious Courts, and the Supreme Court have agreed that a share transfer of the inheritance of a Muslim decedent to non-Muslim beirs through the application of bequests. The application of bequests were first decided by the DKI Jakarta High Religious Court which was later confirmed by the Supreme Court decision No. 368.K/AG/1995. This decision has become jurisprudence and the basis for legal reference for subsequent judges' decisions in resolving the similar legal problems. This paper seeks to examine several legal issues, namely the regulation regarding bequest distribution between religions according to the Islamic inheritance law. Then the author aims at examining the underpinning principles of interreligious bequest application in several judges' decisions in the settlement of disputes over inheritance between religions in court and analyzing them from the perspective of Islamic law. The research method used in this study is the normative - empirical legal research. Apart from reviewing the legal aspects in the statutory regulations, legal facts in the judge's decision regarding the bequest application in settling interfaith inheritance disputes are also examined.

Kata kunci : hukum waris, wasiat wajibah, hukum Islam

Abstrak : Sistem hukum waris Islam secara normatif mengatur bahwa perbedaan agama menjadi salah satu sebab penghalang waris mewarisi (mawani' al-irtsi) antara ahli waris dengan pewarisnya. Namun dalam praktiknya, Pengadilan Agama, Pengadilan Tinggi Agama, maupun Mahkamah Agung bersepakat memberikan bagian harta peninggalan pewaris yang beragama Islam kepada ahli waris non Islam melalui penerapan pemberian wasiat wajibah. Pemberian wasiat wajibah pertama kali diputuskan oleh Pengadilan Tinggi Agama DKI Jakarta yang kemudian dikukuhkan melalui putusan Mahkamah Agung Nomor 368.K/AG/1995. Putusan ini telah menjadi yurisprudensi dan menjadi menjadi dasar rujukan hukum bagi putusanputusan hakim berikutnya dalam menyelesaikan persoalan hukum yang sama. Tulisan ini berupaya mengkaji beberapa persoalan hukum, yaitu pengaturan mengenai pembagian waris beda agama dikaitkan dengan wasiat wajibah menurut Hukum Islam. Kemudian penulis berupaya mengkaji dasar-dasar penerapan wasiat wajibah dalam beberapa putusan hakim dalam penyelesaian sengketa waris beda agama di Pengadilan dan menganalisisnya ditinjau dari perspektif hukum Islam. 
Metode penelitian yang digunakan dalam kajian ini, yaitu metode penelitian hukum normatif - empiris. Selain mengkaji aspek hukum dalam peraturan perundanganundangan, juga menelaah fakta-fakta hukum dalam putusan hakim mengenai penerapan wasiat wajibah dalam penyelesain sengketa waris beda agama.

\section{PENDAHULUAN}

Perbincangann persoalan sengketa pembagian waris beda agama hingga saat ini selalu menjadi kajian diskursif yang seringkali mengundang perdebatan dikalangan ahli hukum maupun praktisi hukum di Indonesia. Hal ini karena penyelesaian sengketa waris beda agama selalu menyentuh persoalan yang sensitif. Bangsa Indonesia sebagai bangsa yang majemuk berdasarkan Ketuhanan Yang Maha Esa sangat menghormati perbedaan agama sebagai hak asasi manusia yang wajid dilindungi sekaligus menjunjung tinggi kebebasan bagi pemeluknya untuk menjalankan ajaran agama sesuai dengan agamanya tersebut. Namun demikian, terkadang seringkali terjadi dialektika antara norma hukum agama dengan tuntutan perkembangan hukum yang menghendaki kesetaraan dihadapan hukum terkait dengan persoalan beda agama. Sebagai contoh, secara yuridis normatif, ketentuan hukum waris beda agama dalam perspektif hukum Islam oleh mayoritas ulama dinyatakan sebagai norma hukum taken for granted, ketentuan yang sudah pasti (qath'i) dan tidak bisa direinterpretasi. Namun dalam praktiknya, norma hukum agama dihadapkan dengan tuntutan perkembangan hukum yang terkadang menghendaki hal yang sebaliknya.

Persoalan tersebut yang seringkali muncul ketika seorang pewaris yang beragama Islam meninggal dunia, sementara salah satu ahli warisnya sudah pindah agama ke agama non Islam. Menurut perspektif hukum Islam, seorang ahli waris non Islam tidak memiliki hak untuk mendapatkan harta warisan dari pewarisnya yang beragama Islam. ${ }^{1}$ Kebebasan beragama dan hak waris merupakan dua persoalan yang berbeda. Kebebasan beragama merupakan hak asasi yang tidak bisa dipaksakan dan harus dihormati. Sementara hak waris merupakan norma hukum yang secara yuridis normatif telah ditetapkan dalam hukum Islam. Para ulama mazhab fiqih sepakat menyatakan bahwa perbedaan agama menjadi salah satu sebab terhalangnya seseorang untuk saling mewarisi antara seorang yang beragama Islam dengan non Islam. ${ }^{2}$

${ }^{1}$ Larangan saling mewarisi antara seorang yang beragama Islam dengan non Islam didasarkan kepada kemumuman isi dari Surat Annisa (4) ayat 141. Kemudian dipertegas dan diperinci oleh Hadits yang diriwayatkan oleh Bukhari dan Muslim yang menyatakan bahwa "orang Islam tidak berhak mewarisi harta orang non Islam dan orang non Islam tidak berhak mewarisi harta orang Islam.”

2 Wahbah Al Zuhaili, Figh Al Islam Wa Adillatubu, Damaskus: Dar' al-Fikr, 1996, hlm. 255 
Dalam sistem kewarisan Islam di Indonesia terdapat larangan saling mewarisi antara seorang yang beragama Islam dengan non Islam secara implisit telah ditegaskan dalam Pasal 171 huruf c Kompilasi Hukum Islam (KHI) menyatakan; "seorang abli waris ialah orang yang pada saat meninggal dunia mempunyai bubungan darah atau bubungan perkawinan dengan pewaris, beragama Islam dan tidak terbalang karena bukum untuk menjadi abli waris."

Berbagai persoalan muncul terkait dengan pembagian harta waris bagi orang yang berbeda agama. Pluralisme masyarakat dan tata hubungan atau interaksi sosial yang inklusif antar pemeluk agama memungkinkan terjadinya perkawinan beda agama. Pola hubungan sosial yang terbuka juga memungkinkan terjadinya perpindahan agama dari satu agama ke agama lainnya. Persoalan hukum kerapkali muncul tidak hanya terkait status hukum perkawinan beda agama, tetapi juga menyangkut akibat hukumnya termasuk penyelesaian pembagian harta warisan apabila salah satu diantara mereka yang berbeda agama meninggal dunia. Berdasarkan data yang publish di situs resmi Mahkamah Agung dalam direktori putusan terdapat banyak kasus sengketa waris beda agama yang diselesaikan secara hukum sampai pada proses persidangan di pengadilan.

Menurut Undang-Undang Nomor 7 Tahun 1989 tentang Peradilan Agama sebagaimana diubah dengan Undang-Undang Nomor 3 Tahun 2006 tentang Perubahan Atas Undang-Undang Nomor 7 Tahun 1989 tentang Peradilan Agama, Pengadilan Agama berwenang memeriksa dan memutuskan sengketa pembagian harta warisan bagi mereka yang beragama Islam. Ketentuan kompetensi absolut Pengadilan Agama dalam menyelesaikan sengketa waris beda agama juga didasarkan pada asas personalitas keislaman, yang mana agama pewaris menjadi penentu kewenangan mutlak Pengadilan Agama.

Sebelum adanya yurisprudensi putusan pengadilan tahun 1995, Pengadilan Agama selalu memberikan putusan secara normatif dengan tidak memberikan harta warisan pewaris yang beragama Islam kepada orang yang beragama non Islam. Putusan pemberian wasiat wajibah sebagai solusi penyelesaian sengketa waris beda agama dicetuskan oleh Putusan Pengadilan Tinggi Agama Jakarta yang dalam putusannya memberikan harta peninggalan pewaris yang beragama Islam kepada ahli waris yang non Islam melalui konsep wasiat wajibah sebesar $3 / 4$ dari perolehan sebagai anak perempuan. Putusan tersebut lalu dikuatkan melalui putusan Mahkamah Agung Nomor 368K/AG/1995 yang tidak hanya memberikan harta peninggalan kepada ahli waris non Islam dengan wasiat wajibah tetapi juga menyamakan perolehan harta warisan ahli waris non Islam dengan ahli waris 
yang beragama Islam. Putusan Mahkamah Agung ini kemudian menjadi yurisprudensi dan sandaran bagi hakim sesudahnya dalam memutuskan sengketa hukum yang sama.

Putusan tersebut juga yang mengilhami putusan sesudahnya, Putusan Mahkamah Agung RI No: 51K/AG/1999, tanggal 29 September 1999 yang memutuskan menempatkan ahli waris non Islam sebagai ahli waris pengganti yang memperoleh harta warisan dari pewaris beragama Islam dengan bagian yang sama dengan ahli waris lainnya yang Islam. Ahli waris beragama Islam tetap mendapatkan warisan dari pewaris Islam melalui penerapan wasiat wajibah yang bagiannya sama dengan bagian anak perempuan sebagai ahli waris.

Putusan hakim dalam yurisprudensi Putusan Mahkamah Agung dan putusanputusan agama lainnya masih menyisakan perdebatan di kalangan ahli hukum maupun praktisi hukum. Hal tersebut terjadi karena putusanya pemberian wasiat wajibah dalam praktik penyelesaian sengketa waris beda agama masih banyak menunjukkan perbedaan pandangan mengenai konsep wasiat wajibah, dasar penerapan hukum, dan bagian dari harta peninggalan atau harta warisan serta jumlah bagian yang dapat diberikan.

Oleh karena itu, kajian mengenai penerapan wasiat wajibah dalam putusan penyelesaian sengketa waris beda agama ditinjau dari perspektif hukum Islam tetap menarik untuk diteliti. Penulis berupaya mengkaji dengan analisis kualitatif beberapa permasalahan hukum.

Terdapat beberapa rumusan masalah hukum yang akan dikaji oleh penulis dalam tulisan ini. Pertama, bagaimana pengaturan pembagian waris beda agama dikaitkan dengan wasiat wajibah menurut Hukum Islam? Kedua, apa dasar-dasar penerapan wasiat wajibah dalam beberapa putusan hakim dalam penyelesaian sengketa waris beda agama di Pengadilan. Kemudian penulis berupaya menganalisis masalah penerapan wasiat wajibah dalam putusan hakim sebagai solusi penyelesaian sengketa waris beda agama ditinjau dari perspektif hukum Islam?

\section{METODE PENELITIAN}

Tulisan ini menggunakan metode penelitian hukum normatif-empiris yang mengkombinasikan antara penelitian hukum normatif dengan penelitian hukum empiris. Penelitian ini selain memfokuskan pada penelurusan mengenai norma-norma hukum tentang masalah hukum tertentu sebagaimana yang termaktub di dalam peraturan perundang-undangan (law in the books) tetapi mengkaji berlakunya hukum (law in action) di dalam masyarakat atau yang diterapkan dalam praktik penegakan hukum di Pengadilan. 
Penelitian hukum normatif ini berupaya mengkaji mengenai pengaturan masalah pembagian waris beda agama dikorelasikan dengan konsep wasiat wajibah sebagaimana yang dikonsepkan dan diatur dalam Hukum Islam dan Kompilasi Hukum Islam serta dasar-dasar penerapan wasiat wajibah dalam beberapa putusan hakim dalam penyelesaian sengketa waris beda agama di Pengadilan Agama maupun di dalam yurisprudensi putusan Mahkamah Agung. Sementara penelitian hukum empiris dilakukan dengan dilakukan dengan teknik wawancara (dept interview) dengan beberapa hakim di Pengadilan Agama yang berada di wilayah yurisdiksi DKI Jakarta. Hal itu dilakukan untuk mengetahui ratio decidendi-nya, yaitu alasan hukum yang digunakan oleh hakim dalam memutuskan sengketa waris beda agama. Kemudian melakukan wawancara dengan beberapa narasumber dari kalangan MUI Pusat, akademisi, maupun pengacara yang kompeten di bidang keahliannya.

Penelitian ini menggunakan pendekatan peraturan perundang-undangan pendekatan konseptual (conceptual approach), (statute approach), dan pendekatan kasus (case approach). Pendekatan konseptual digunakan sebagai upaya menelaah konsep hukum waris beda agama dan kolerasinya dengan konsep wasiat wajibah dari perspektif hukum Islam dan Kompilasi Hukum Islam. Pendekatan perundang-undangan (statute approach) dilakukan dengan menelaah semua peraturan perundang-undangan yang relevan dengan isu hukum mengenai putusan penyelesaian sengketa waris beda agama, sehingga dapat diketahui ratio legis dari putusan tersebut. Sementara pendekatan kasus digunakan sebagai upaya mengkaji secara mendalam ratio legis yang menjadi dasar pertimbangan hakim dalam putusan penyelesaian sengketa waris beda agama dan penerapan wasiat wajibah sebagai solusi penyelesaian hukum atas permasalahan tersebut.

\section{PEMBAHASAN}

\section{A. Pengaturan Waris Beda Agama Dikaitkan Dengan Konsep Hukum Wasiat}

\section{Wajibah Menurut Hukum Islam Dan Kompilasi Hukum Islam}

Persoalan Agama merupakan hal yang sangat fundamental dalam hukum Islam. Perbedaan agama merupakan sesuatu yang niscaya dan terjadi dalam kehidupan masyarakat yang bersifat majemuk yang memungkinkan terjadinya interaksi yang inklusif antar pemeluk agama. Perbedaan agama selain karena factor keturunan dapat terjadi karena perkawinan beda agama atau perpindahan agama. Ada tiga hal yang menjadi penghalang hak waris seseorang, yaitu pembunuhan, perbedaan agama atau perbudakan. ${ }^{3}$ 
Perbedaan agama yang dimaksud terjadi apabila seorang yang meninggal beragama atau pewaris beragama Islam sementara ahli warisnya beragama non Islam atau sebaliknya.

Perbedaan agama dalam hukum Islam berimplikasi terhadap hak waris seseorang. Apabila terdapat perbedaan agama antara pewaris dengan ahli waris, maka secara normatif, ia tidak berhak mendapatkan harta warisan. Ketentuan hukum tersebut secara eksplisit tidak disinggung dalam Al-Qur'an, tetapi Hadits Nabi Muhammad SAW yang diriwayatkan oleh Imam Bukhari dan Muslim secara tegas menyatakan, artinya: "Tidaklah berbak seorang muslim mewarisi harta orang kafir, dan tidak berhak, pula orang kafir mewarisi harta seorang muslim". Kemudian Hadits Nabi Muhammad SAW dalam riwayat lainnya, juga menegaskan "tidak dapat saling mewarisi antara dua orang pemeluk agama yang berbeda."

Dalam pandangan konsep fiqih konvensional berdasarkan pendapat mayoritas ulama mazhab hukum dalam hukum Islam seperti keempat Imam Mujtahid yaitu Imam Abu Hanifah, Imam Malik, Imam Asy-Syafi'i dan Imam Ahmad bin Hanbal menyatakan bahwa seorang muslim tidak bisa mewarisi harta seorang non muslim dan sebaliknya seorang non muslim tidak dapat mewarisi harta seorang muslim. ${ }^{4}$ Penentuan terhalang atau tidaknya seseorang dari hak warisnya dilihat dari waktu pada saat pewaris meninggal dunia. Seorang yang ahli waris yang beragama non Islam sebelum pewarisnya meninggal maka ia tidak berhak lagi atas hak waris dari pewaris yang beragama Islam. Apabila ahli waris non Islam masuk Islam setelah pewaris yang beragama Islam meninggal dunia, maka ia tetap terhalang dari hak warisnya.

Sebelum membicarakan waris dikorelasikan dengan wasiat wajibah, ada baiknya penulis mengkaji lebih dulu mengenai korelasi waris dengan konsep hukum lainnya, yaitu hibah dan wasiat. Ketiganya seringkali tidak dapat dipisahkan dalam praktik kehidupan masyarakat.

Konsep hukum hibah, wasiat, dan waris memiliki persamaan dan perbedaan dalam ketentuan hukum, diantaranya terdapat persamaan dan perbedaan, yaitu dari segi pembuat, waktu pelaksanaan, dan jumlahnya. Secara umum ketiganya memiliki persamaan, yaitu adanya pengalihan harta dari seseorang kepada orang lain. Baik hibah maupun wasiat sama-sama merupakan perjanjian sepihak dari pembuat hibah dan wasiat yang menginginkan pemindahan hak miliknya kepada orang lain pada saat mereka masih hidup. Sedangkan dalam hukum waris sama sekali tidak terkait dengan kehendak pewaris

${ }^{4}$ Syaikh Abdurrahman Al Juzairi, Kitabul Fiqhi Ala al-Madzabib al-Arbaah, Beirut: Daar al-Dayyan Li al-Turats, juz III, hlm. 287-288. Lihat juga Wahbah Al Zuhaili, Op. Cit., hlm. 255 
melainkan ketentuannya sudah imperatif berdasarkan hukum Islam yang bersifat keharusan (ijbari).

Berkaitan dengan waktu pelaksanaan, pemindahan hak milik melalui hibah dapat direalisasikan pada saat pemberi hibah menyatakan kehendaknya dan keberlakuannya tanpa harus menunggu pemberi hibah meninggal dunia. Sementara wasiat, keberlakuan pelaksanaannya harus menunggu pewasiat meninggal dunia lebih dulu baru dapat direalisasikan secara hukum. Berbeda dengan hibah dan wasiat, hukum waris, khususnya hukum waris berdasarkan hukum Islam, pemindahan hak milik pewaris kepada ahli waris berlaku sejak adanya kepastian hukum pewaris meninggal dunia. ${ }^{5}$

Sementara itu, istilah wasiat wajibah merupakan istilah baru yang pertama kali dipopulerkan di Mesir melalui hukum waris tahun 1946 sebagai salah satu reformasi hukum di bidang hukum keluarga. Definisi wasiat wajibah dalam Ensiklopedi Hukum Islam diartikan suatu wasiat yang diperuntukkan kepada para ahli waris atau kerabat yang tidak memperoleh bagian harta warisan dari orang yang wafat, karena adanya suatu halangan syara'. ${ }^{6}$ Sementara dalam pengertian praktis, wasiat wajibah diartikan sebagai tindakan yang dilakukan penguasa atau hakim untuk memaksa atau memberi putusan wajib wasiat bagi orang yang telah meninggal dunia yang diberikan kepada orang tertentu dalam keadaan tertentu. ${ }^{7}$ Dengan demikian, implementasi wasiat wajibah tidak dipengaruhi oleh kemauan atau kehendak si pemberi wasiat, melainkan ditetapkan berdasarkan putusan hakim.

Istilah wasiat wajibah sebenarnya merupakan hasil ijtihad ulama kontemporer dalam menafsirkan surat Al-Baqarah (2) ayat 180 yang artinya "diwajibkan atas kamu, apabila maut hendak menjemput seseorang di antara kamu, jika dia meninggalkan harta, berwasiat untuk kedua orang tua dan karib kerabat dengan cara yang baik, (sebagai) kewajiban bagi orang-orang yang bertakwa". Ayat tersebut menjelaskan mengenai konsep wasiat secara umum. Para ulama berbeda pendapat dalam menafsirkan konsep wasiat dalam surat Al-Baqarah (2) ayat 180. Sebagian besar ulama fiqih menyatakan bahwa hukum wasiat adalah tidak wajib. ${ }^{8}$ Sementara sebagian ulama lainnya menyatakan bahwa hukum wasiat adalah wajib.

\footnotetext{
${ }^{5}$ Sayid Sabiq, Figh Al Sunnah, juz 3, Kairo: Maktabah Dar al Turast, tt, hlm 414), lihat juga Ibnu Rusyd, Bidayatul Mujtahid, Juz 2, Semarang: Usaha Keluarga, tt

6 Abdul Aziz Dahlan (ed), Ensiklopedi Hukum Islam, Jakarta: PT. Ichtiar Baru van Hoeve, 1996, hlm. 1930. Lihat juga TM. Hasbi Ash-Shiddiqy, Fiqih Mawaris, Semarang: PT. Pustaka Rizki Putra, 1999, hlm. 274.

7 Abdul Manan, Beberapa Masalah Hukum tentang Wasiat dan Permasalahannya dalam Konteks Kewenangan Peradilan Agama”, Mimbar Hukum Aktualisasi Hukum Islam Nomor 38, Vol. IX, 1998, hlm. 23

${ }^{8}$ Wahbah Al Zuhaili, Op.Cit., hlm. 54
} 
Pandangan pertama berpendapat bahwa hukum wasiat itu tidak wajib. Pandangan ini dianut oleh Imam mazhab yang empat; Imam Hanafi, Imam Malik, Imam Syafi'i, dan Imam Hambali, golongan Zaidiyah, dan Imamiyah. Ada beberapa argumentasi hukum yang mereka gunakan dalam memperkuat pendapat tersebut. Diantara dasar agumentasi tersebut yang pertama adalah tidak ada riwayat dari para sahabat bahwa kebanyakan sahabat Nabi SAW berwasiat pada masa mereka hidup. Kedua, sebagaimana hibah, wasiat merupakan pemberian atas dasar kesukarelaan dari pemberi tersebut yang merupakan bagian dari kebajikan dari orang memberikan wasiat itu sendiri. Ketiga, hukum wasiat yang dipahami dari surat Al-Baqarah ayat 180 yang memerintahkan wasiat dianggap telah dihapus hukumnya (nasakh) oleh ayat-ayat yang menjelaskan tentang hukum waris ${ }^{9}$ dan hadits Nabi SAW diriwayatkan oleh Imam At-Turmudzi yang menegaskan bahawa "tidak boleh berwasiat kepada ahli waris". ${ }^{10}$ Keempat, perintah untuk berwasiat yaitu dalam rangka untuk menambah amal kebajikan (amalu al-shalib). hal ini didasarkan pada hadits yang diriwayat oleh Abu Darda' yang menyatakan bahwa Nabi SAW pernah bersabda, "Allah telah memerintabkan kepadamu untuk mengeluarkan sepertiga dari hartamu sebagai wasiat untuk tambahan amal bagimu". ${ }^{11}$

Sementara pandangan kedua yang direfresentasikan oleh Ibn Hazm menyatakan bahwa hukum wasiat adalah wajib. Bahkan ia menyatakan bahwa wasiat kepada kedua orang tua dan kerabat dekat yang tidak mendapatkan hak waris hukumnya wajib, baik itu karena perbedaan agama, perbudakan, atau karena ada ahli waris lain terdekat yang utama menghalanginya (menghijab-nya). ${ }^{12}$ Bahkan menurut Ibn Hazm apabila pewaris pada masa hidup belum sempat membuat wasiat maka ahli waris wajib mengeluarkan sedekah sebagian harta peninggalan pewaris untuk kerabatnya. ${ }^{13}$

Pendapat Ibn Hazm diperkuat dengan beberapa argumentasi untuk memperkuat pandangannya. Pertama, seluruh ayat Al-Qur'an itu pada dasarnya mubkamat, arti lafadh dan makna lahirnya sudah jelas dan tidak mungkin diganti. Oleh karena itu, hukum dalam Al-Qur'an tidak ada istilah menghapus atau dihapus hukumnya (nasikh - mansukh). Jadi surat Al-Baqarah ayat 180 tidak dihapus ketentuan hukumnya dengan ayat-ayat tentang hukum waris (mawaris), melainkan dijelaskan oleh ayat-ayat tentang hukum waris.

${ }_{9}^{9}$ Ismail bin Katsir, Tafsir Ibnu Katsir, Jilid I, Mesir: Dar al-Hadits, hlm. 112

10 Al-Turmudzi, Sunan Al-Turmudzi, Beyrut: Daar al-Fikr, 1980, juz II, hlm. 292. Lihat juga Sri Hidayati, Ketentuan Wasiat Wajibah di Pelbagai Negara Muslim Kontemporer. Jakarta: Jurnal Ahkam, Vol.XII, No.1, Januari 2012, hlm. 82

${ }^{11}$ Ibn Qudamah, Al-Mughni, Beirut: Dar' al-Kitab Al-Ilmiyyah, tth, juz VI, hlm.415

12 Wahbah Al Zuhaili, Op. Cit., hlm. 58

${ }^{13}$ Ibn Hazm, Al-Muhalla, juz X, al-Qahirah: Maktabah al-Jumhuriyyah al-Arabiyyah, 1970, hlm. 
Pendapat ini didukung dengan surat An-Nisa ayat 11 dan 12 yang mengaitkan pelaksanaan hukum waris setelah adanya pemenuhan kewajiban pembayaran wasiat dan hutang.

Pendapat kedua tersebut kemudian dipahami dan dikembangkan oleh sebagian ulama dalam merespon perubahan dan tuntutan hukum dalam kehidupan masyarakat. Ketentuan bahwa wasiat itu wajib lalu diintrodusir oleh kalangan ulama di beberapa negara menjadi wasiat wajibah untuk menjawab kebutuhan hukum di masyarakatnya.

Undang-Undang Mesir memformulasikan bentuk wasiat menjadi wasiat wajibah menjadi sesuatu yang diwajibkan dan dibebankan kepada pewaris untuk melaksanakannya tercantum di dalam Qonun No.71 Tahun 1946. ${ }^{14}$ Ketentuan wasiat wajibah diberikan kepada cucu sebagai ahli waris pengganti dari orang tuanya yang telah meninggal lebih dulu dari kakeknya dengan jumlah bagian yang sama dengan yang diterima semestinya oleh orang tuanya jika mereka hidup. Ketentuan ini juga diikuti oleh beberapa negara muslim lainnya, seperti Syiria, Tunisia, Maroko, Kuwait, Irak, Yordan, dan Pakistan. Namun demikian, dalam penerapan pemberian wasiat wajibah, terdapat beberapa perbedaan, yaitu terkait cucu yang mana saja yang boleh menerima wasiat wajibah.

Di dalam peraturan undang-undang Kuwait dalam Qonun al-Washiyah al-Wajibah 1971, ketentuan pemberian wasiat wajibah hanya dapat diberikan kepada anak laki-laki dari garis keturunan laki-laki (Ibn al-Ibn) dan seterusnya ke bawah. Sementara untuk garis keturunan perempuan, yang berhak menerima wasiat wajibah hanya garis keturunan yang pertama saja. Ketentuan ini juga tidak jauh berbeda dengan ketentuan wasiat wajibah di negara Maroko.

Sedangkan Syiria dan Jordania menentukan aturan yang berbeda dengan beberapa negara mulsim lainnya. Undang-undang mereka hanya menentukan pemberian wasiat wajibah hanya untuk cucu garis keturunan anak laki-laki saja, sementara cucu garis keturunan perempuan sama sekali tidak mendapatkan hak memperoleh wasiat wajibah. ${ }^{15}$

Ketentuan mengenai wasiat wajibah di Indonesia dapat dilihat dalam Kompilasi Hukum Islam (KHI) melalui Instruksi Presiden No. 1 Tahun 1991 tentang Kompilasi Hukum Islam. Satu-satunya yang menyinggung masalah wasiat wajibah adalah Pasal 209 yang mengatur mengenai pemberian wasiat wajibah dari pewaris orang tua angkat kepada anak angkatnya, atau sebaliknya.

Sementara itu, berkaitan dengan penerapan wasiat wajibah dalam konteks pembagian waris beda agama, KHI secara eksplisit tidak menjelaskan mengenai hal

${ }^{14}$ Sri Hidayati, Ketentuan Wasiat Wajibah di Pelbagai Negara Muslim Kontemporer, Jakarta, Jurnal Ahkam, Vol. XII, No.1 Januari 2012, hlm. 83

${ }^{15}$ Ibid., hlm. 84-85 
tersebut. Pasal yang menyinggung masalah wasiat wajibah dalam pasal 209 KHI hanya mengatur masalah pembagian waris antara pewaris dengan anak angkatnya atau sebaliknya. Dalam pengaturan tentang wasiat, KHI tidak pernah menyebutkan ketentuan wasiat atau wasiat wajibah terhadap orang yang berbeda agama, melainkan hanya menjelaskan siapa saja yang berhak mendapatkan wasiat beserta syarat dan rukunnya. Dengan demikian, KHI tidak pernah menjelaskan masalah wasiat atau wasiat wajibah dengan mengkolerasikannya dengan waris beda agama. Namun demikian, KHI juga tidak mengatur satu pasalpun yang melarang memberikan wasiat atau wasiat wajibah kepada ahli waris yang berbeda agama.

Larangan pembagian bagi orang yang berbeda agama secara implisit dipahami dari Pasal 171 huruf c KHI yang menjelaskan bahwa yang dimaksud ahli waris adalah "orang yang pada saat meninggal dunia mempunyai bubungan darah atau bubungan perkawinan dengan pewaris, beragama Islam dan tidak terbalang karena bukum untuk menjadi abli waris". Pasal ini seringkali dijadikan dasar larangan saling mewarisi antara orang yang beragama Islam dan non Islam. Pendapat ini didasarkan pada pendapat mayoritas ulama mazhab fiqih yang menyatakan larangan saling mewarisi antara orang yang berbeda agama.

Namun demikian, para ulama membolehkan berwasiat kepada seorang non muslim atau berbeda agama. Hal itu karena berwasiat, baik kepada orang muslim atau kepada orang yang tidak beragama Islam (ghairul al-Islam) dianggap salah satu bentuk kebajikan. ${ }^{16}$ Tindakan wasiat yang dilakukan tersebut sama saja dengan membangun hubungan baik atau muamalah yang sangat dianjurkan dalam Islam.

Meskipun hukum waris Islam tidak memberikan hak saling mewaris antar orangorang yang berbeda agama (antara muslim dengan non-muslim), tetapi terdapat ketentuan yang menyatakan bahwa pemberian harta antar orang berbeda agama dapat dilakukan dalam bentuk pemberian hibah, wasiat dan hadiah. Pendapat ini selaras dengan Fatwa Majelis Ulama Indonesia (MUI) hasil MUNAS Nomor: 5/MUNAS VII/MUI/9/2005 yang dilaksanakan 26-29 Juli 2005 tentang Kewarisan Beda Agama, yang menetapkan bahwa :

a. Hukum waris Islam tidak memberikan hak saling mewaris antar orang-orang yang berbeda agama (antara muslim dengan non-muslim).

b. Pemberian harta antar orang berbeda agama hanya dapat dilakukan dalam bentuk hibah, wasiat dan hadiah.

${ }^{16}$ Wahbah Al Zuhaili, Op. Cit., hlm. 58 
Menurut Fatwa MUI, larangan saling mewarisi tersebut bersifat mutlak (taken for granted) dan tidak bisa diinterpretasi ulang karena didasarkan kepada dalil Al-Qur'an dan Hadits yang pasti (qath'i). Tetapi hukum Islam masih memberikan ruang terbuka bagi setiap orang yang berbeda agama agar bisa saling mengasihi melalui instrumen konsep hukum lainnya, yaitu seperti hibah, wasiat, dan hadiah. Hal ini dikarenakan penetapan ketiga konsep hukum tersebut cakupannya lebih luas dan tidak terbatas hanya untuk orang yang satu agama saja melainkan bisa juga diterapkan untuk mereka berbeda agama selain Islam.

\section{B. Dasar-Dasar Penerapan Wasiat Wajibah Terkait Penyelesaian Sengketa Waris Beda Agama Dalam Yurisprudensi Putusan Hakim}

Penyelesaian hukum pembagian waris dari harta peninggalan pewaris muslim dan wasiat merupakan salah satu kewenangan absolut Pengadilan Agama yang diatur dalam Pasal 49 UU No. 3 Tahun 2006 tentang Perubahan Atas UU No. 7 Tahun 1989 tentang Peradilan Agama. Oleh karena itu, selaras dengan asas personalitas keislaman, bahwa untuk menentukan kewenangan Pengadilan Agama atau tidaknya dilihat dari agama pewaris atau orang yang meninggalkan harta warisan itu sendiri dan bukan pada agama ahli waris yang bisa saja berbeda antara satu ahli waris dengan ahli waris lainnya.

Berdasarkan hasil penelitian kepustakaan dalam beberapa putusan pengadilan, baik putusan Pengadilan Agama, Pengadilan Tinggi, maupun Mahkamah Agung ditemukan fakta-fakta hukum dalam putusan hakim mengenai penyelesaian sengketa waris beda agama dengan memberikan bagian harta peninggalan pewaris yang muslim kepada ahli waris yang non muslim melalui penerapan wasiat wajibah. Selain itu, melalui penelitian empiris dengan teknik wawancara mendalam (dept interview) dengan beberapa hakim Pengadilan Agama di wilayah hukum DKI Jakarta ditemukan pula dasar-dasar penerapan wasiat wajibah dalam beberapa putusan hakim Pengadilan Agama dan Yurisprudensi Putusan Mahkamah Agung tentang penyelesaian sengketa waris beda agama sebagai berikut :

Pertama, alasan hirstoris hukum Islam. Larangan pembagian waris terhadap ahli waris non-muslim secara historis ditetapkan pada masa peperangan antara kaum muslimin dengan orang kafir bangsa Arab di masa lalu. Untuk menjaga aqidah dan harta yang dimiliki seorang muslim dari penguasaan non muslim yang berpotensi untuk digunakan sebagai alat untuk memerangi umat Islam. 
Dalam sejarah hukum Islam, pemberian warisan antara orang yang berbeda agama juga pernah dipraktikkan oleh sahabat Nabi SAW. Seorang sahabat bernama Muadz bin Jabal pernah memutuskan memberikan harta warisan pewaris yang beragama Yahudi kepada ahli waris yang beragama Islam. Untuk menyelesaikan masalah hukum tersebut. Pendapat ini juga diikuti oleh sebagian ulama lainnya yang membolehkan ahli waris yang beragama Islam menerima pembagian harta warisan dari mereka yang beragama non Islam. Pendapat ini kemudian dijadikan dasar pemikiran oleh sebagian hakim mengenai kemungkinan pemberian harta warisan untuk kasus sebaliknya, dimana seorang non Islam dimungkinkan mendapat hak waris yang sama dari pewaris muslim. selain itu, kehidupan masyarakat yang majemuk dalam negara kesatuan menghendaki adanya kesamaan kedudukan di depan hukum (equaliy before the law).

Kedua, alasan adanya kemaslahatan dan keadilan. Sebagai upaya menyelesaian masalah-masalah hukum yang tidak diatur secara detail di dalam peraturan perundangundangan. Maka hakim dapat menggunakan dasar adanya kemasalahatan yang lebih besar. Menurut salah seorang hakim di Pengadilan Agama menyatakan seorang terlahir dari keluarga muslim dan apabila dia berpindah agama maka kedudukannya sebagai anak tidak serta merta hilang. Melainkan seorang ayah tetap memiliki kewajiban terhadap anaknya tersebut, seperti hak nafkah dan lain sebagainya.

Dalam menyelesaikan hukum terhadap ahli waris yang berbeda agama, menurut hakim yang hilang hanyalah hak warisnya karena adanya perbedaan agama yang dilarang secara tegas oleh hukum Islam untuk saling mewarisi. sementara hak lainnya seperti hibah atau wasiat masih dimungkinkan sepanjang adanya kemaslahatan yang lebih utama. Sebagai contoh, seorang ahli waris yang berbeda agama dengan kondisi ekonominya yang lemah sementara saudaranya yang lain dan kebetulan beragama Islam relatif memiliki tingkat ekonomi yang lebih berkecukupan. Sebagai upaya menyelesaikan masalah tersebut, maka hakim dapat memutuskan memberikan wasiat wajibab terhadap ahli waris yang non muslim tersebut dengan kemaslahatan kehidupan si anak.

Selain itu, dalam menegakkan hukum atau undang-undang, hakim dapat mengutamakan nilai-nilai keadilan yang menjadi tujuan utama hukum Islam. Hakim bukanlah petugas undang-undang, melainkan aparat penegak hukum yang diberi tugas dan tanggung jawab untuk menegakkan hukum dan keadilan. Namun demikian, tidak seluruh aturan hukum itu inheren dengan sebuah keadilan. Terkadang peraturan atau undangundang perlu diterobos untuk mencapai tujuan keadilan. Keadilan yang dimaksud oleh 
hakim adalah keadilan yang sebenarnya dengan melihat kasus per kasus yang dihadapi dan tidak bisa digeneralisasi dapat berlaku untuk semua kasus hukum yang ada. ${ }^{17}$

Ketiga, penggunaan metode interpretasi dalam penemuan hukum. Hakim diberi tugas dan tanggung jawabnya sebagai seorang hakim untuk memeriksa semua perkara yang dijaukan kepadanya. Dalam mengemban tugas tersebut adakalanya kasus-kasus hukum tidak selalu ditemukan rumusan hukumnya di dalam undang-undang. Namun demikian, sesuai ketentuan pasal 10 UU No. 48 Tahun 2009 tentang Kekuasan Kehakiman menyatakan bahwa hakim tidak dapat menolak untuk mengadili perkara yang diajukan ke pengadilan dengan dalih hukum tidak ada atau kurang jelas, melainkan harus memeriksa, mengadili, dan memutuskannya. Hal ini sejalan dengan adagium ius curia novit, dimana hakim dianggap mengetahui dan memahami hukum. ${ }^{18}$

Oleh karena itu, Salah satu upaya yang dapat dilakukan hakim yaitu menggunakan metode interpretasi dalam rangka penemuan hukum (rechtsvinding) untuk menyelesaikan masalah-masalah hukum baru. Putusan penerapan wasiat wajibah bagi ahli waris yang terhalang untuk menerima warisan karena tidak beragama Islam merupakan hasil dari interpretasi hakim dalam rangka penemuan hukum (rechtsvinding) dalam menyelesaikan masalah hukum tersebut.

Penggunaan metode interpretasi berasal dari pemahaman bahwa ketentuan mengenai hukum kewarisan Islam merupakan lex specialis dari hukum Islam sebagai lex generalis. Berdasarkan hal tersebut, apabila hakim tidak menemukan ketentuan mengenai wasiat wajibah bagi ahli waris yang terhalang karena tidak beragama Islam dalam hukum kewarisan Islam sebagai lex specialis, maka hakim dapat melakukan penemuan hukum dengan mengembalikan persoalan pembagian bagi ahli waris non muslim pada ketentuan lex generalis dalam hukum Islam melalui penerapan ketentuan lex generalis dilakukan dengan menggunakan beberapa asas hukum, yaitu asas keadilan berimbang, asas kepastian, asas individual, dan asas bilateral. Asas-asas ini merupakan tujuan objektif bagi penerapan hukum Islam secara keseluruhan. Hakim dapat menggunakan asas-asas tersebut untuk menetapkan pemberian wasiat wajibah bagi ahli waris yang beda agama sebagai ketentuan lex generalis hukum Islam. ${ }^{19}$

17 Ajat Sudrajat, Hakim Pengadilan Agama Jakarta Utara \& Hj. Sanijalker, Hakim Pengadilan Jakarta Pusat, dalam laporan penelitian Ahmad Baihaki, Penerapan W asiat W ajibah dalam Penyelesaian Sengketa Pembagian Waris Beda Agama di Lingkungan Pengadilan Agama DKI Jakarta, dalam Laporan Penelitian Hukum Tabun 2015, hlm. 51

${ }^{18}$ Ibid., hlm. 52

${ }_{19}$ Destri Budi Nugraheni dkk, Pengaturan dan Implementasi Wasiat W ajibah di Indonesia, Jurnal Mimbar Hukum, Volume 22, Nomor 2, Juni 2010, hlm. 318-321 
KRTHA BHAYANGKARA | Volume 15 Number 1, June 2021

Keempat, Penggunaan metode argumentum per analogium. Penggunaan metode argumentum per analogium yang dalam konsep hukum Islam dikenal dengan metode qiyas yaitu menganalogikan kedudukan orang berbeda agama (non Islam) sama dengan orang yang berdasarkan dasar hukum waris tidak berhak untuk mendapatkan hak waris dari pewaris muslim dengan ketentuan lain, yaitu anak angkat yang juga bukan ahli waris tetapi oleh KHI diberikan hak mendapatkan harta peninggalan orang tua angkatnya sebagai pewaris melalui konsep wasiat wajibah.

Upaya hakim dalam penemuan hukum atas pemberian wasiat wajibah terhadap ahli waris yang tidak beragama Islam dengan menggunakan metode qiyas atau argumentum per analogium. Upaya ini dilakukan dengan cara menemukan ketentuan hukum lain yang sejenis, memiliki alasan atau dasar penetapan hukum yang sama, serta adanya tuntutan dalam masyarakat untuk mendapatkan penilaian yang sama. Ketentuan yang sejenis untuk mengatasi kekosongan dalam hal ini adalah menggunakan ketentuan Wasiat Wajibah yang ada di dalam KHI khusus untuk anak angkat dan atau orang tua angkat. ${ }^{20}$

Penggunaan argumentum per analogium dalam konteks hukum Islam biasanya dikenal dengan metode qiyas. Metode qiyas yaitu menyamakan suatu ketentuan hukum tertentu yang belum ada rumusan hukumnya dengan ketentuan hukum yang sudah diatur dalam Al-Qur'an atau Hadits karena ada kemiripan diantara keduanya. Menurut hukum Islam, orang yang berbeda agama yang secara yuridis formal tidak mendapatkan bagian harta waris meskipun mereka memiliki hubungan nasab atau kekeluargaan dengan pewaris baik sebagai anak kandung maupun anak angkat. Dengan adanya kesamaan tersebut, maka aturan yang berlaku pada satu peristiwa diberlakukan pula pada peristiwa lain, sehingga ketentuan wasiat wajibah bagi anak angkat diberlakukan pula pada anak yang tidak beragama Islam. Inilah yang kemudian merupakan penemuan hukum yang dilakukan oleh hakim dengan menggunakan metode argumentum per analogium.

\section{Telaah Kritis Terhadap Putusan Hakim Mengenai Penerapan Wasiat Wajibah Sebagai Penyelesaian Hukum Sengketa Waris Beda Agama}

Terdapat banyak putusan pengadilan yang memutuskan sengketa masalah pembagian waris beda agama, baik putusan Pengadilan Agama, Pengadilan Tinggi Agama maupun putusan Mahkamah Agung yang diperoleh melalui situs resmi dalam direktori Putusan

${ }^{20}$ Rusydi Thahir, Hakim Pengadilan Agama Jakarta Selatan, Ajat Sudrajat, Hakim Pengadilan Agama Jakarta Utara, dalam laporan penelitian Ahmad Baihaki, Penerapan Wasiat Wajibah dalam Penyelesaian Sengketa Pembagian Waris Beda Agama di Lingkungan Pengadilan Agama DKI Jakarta, dalam Laporan Penelitian Hukum Tabun 2015, hlm. 53 
Mahkamah Agung. ${ }^{21} \quad$ Penulis hanya mengkaji beberapa putusan dipilih secara random sampling yang relevan dengan beberapa persoalan hukum yang sedang diteliti penulis. Beberapa putusan yang telah diteliti, yaitu:

1) Putusan Pengadilan Tinggi Agama Manado Nomor :01/Pdt.G/2007/PTA.Mdo memberikan warisan dengan wasiat wajibah sejumlah nilai bagian ahli waris perempuan. Dalam putusan tersebut tidak dijelaskan apakah wasiat tersebut diambil dari harta peninggalan atau dari harta warisan yang ada. Melainkan hanya menyebutkan pembagian harta melalui wasiat wajibah diambil dari bagian seluruh harta warisan.

2) Putusan Pengadilan Tinggi Agama Nomor : 18/Pdt.G/2007/PTA.Sby. mendasarkan putusan pada Pasal 171 huruf c jo pasal 174 Kompilasi Hukum Islam, memutuskan bahwa ahli waris yang berbeda agama tidak mendapatkan harta warisan melainkan memperoleh hak/bagian dari harta peninggalan orang tuanya melalui jalur wasiat wajibah yang besarnya sama dengan ahli waris anak laki-laki lainnya.

3) Putusan Pengadilan Agama Surabaya Nomor: 473/Pdt.P/2010/PA.Sby. memutuskan masalah pembagian waris terhadap beberapa ahli waris beragama non muslim dari pewaris yang muslim. Meskipun tidak menilai mereka sebagai ahli waris tetapi majelis hakim tetap memberikan harta warisan sebagai penerima wasiat wajibah.

4) Putusan Pengadilan Agama Kabanjahe Nomor : 2/Pdt .G/2011/PA- Kbj Tanggal 24 Pebruari 2011 memberikan putusan tentang pembagian warisan termasuk didalamnya terhadap ahli waris yang beda agama dengan menerapkan wasiat wajibah. Putusan tersebut hanya menyebutkan mendapatkan warisan sebagai wasiat wajibah.

5) Putusan Pengadilan Tinggi Agama Surabaya Nomor: 459/Pdt.G/2013/PTA.Sby.tanggal 13 Pebruari 2014 memutuskan memberikan wasiat wajibah dari harta peninggalan (tirkah) dalam penyelesaian sengketa waris dengan bagian yang tidak melebihi perolehan harta warisan dari ahli waris lainnya yang muslim.

6) Putusan Pengadilan Tinggi Agama Makassar Nomor 43/Pdt.G/2014/PTA.Mks tanggal 8 Juli 2014 memberikan putusan memberikan wasiat wajibah dari harta warisan yang ditinggalkan dengan menggunakan interpretasi hukum atau metode

${ }^{21}$ https://putusan3.mahkamahagung.go.id/direktori.html 
analogi hukum dengan mendasarkan kepada pasal 209 KHI, yurisprudensi putusan MA tahun 1999 tentang wasiat wajibah terhadap ahli waris yang berbeda agama.

7) Putusan Pengadilan Tinggi Agama Pelambang Nomor 05/Pdt.G/2015/PTA.Plbg tanggal 25 Februari 2015 tanggal dengan memutuskan memberikan wasiat wajibah kepada ahli waris yang berbeda agama dari harta peninggalan (warisan) almarhum Vincencius Papilaya, setelah dilunasi hutang-hutang almarhum Vincencius Papilaya bin Yos Papilaya

8) Putusan Mahkamah Agung Nomor: 368 K/AG/1995 tanggal 16 Juli 1995 yang memutuskan memberikan wasiat wajibah dari harta peninggalan pewaris yang beragama Islam kepada anak perempuan kandung yang beragama non Islam

9) Putusan Mahkamah Agung Nomor: 51 K/AG/1999 tanggal 29 September 1999 yang memutuskan memberikan wasiat wajibah dari harta warisan pewaris yang beragama Islam kepada anak kandung yang beragama non Islam sebagai ahli waris pengganti. ${ }^{22}$

Berdasarkan beberapa putusan hakim tersebut, nampak bahwa dalam memberikan putusan mengenai masalah pembagian waris terhadap ahli waris yang berbeda agama dengan agama pewarisnya, sebagian hakim menggunakan dasar hukum KHI Pasal 171 yang menyebutkan ahli waris harus seagama dengan ahli warisnya, sehingga orang yang berbeda agama berdasarkan pasal tersebut tidak dapat saling mewarisi. Namun meski demikian, sejak tahun 1995 melalui putusan Pengadilan Tinggi Agama DKI Jakarta yang kemudian dikuatkan dengan Mahkamah Agung tahun 1995, Majelis Hakim pengadilan selalu menjadinyak putusan tersebut sebagai dasar hukum dalam penerapan wasiat wajibah untuk menyelesaikan pembagian waris antara mereka yang berbeda agama.

Sementara sebagian hakim lainnya tidak menyebutkan dasar hukum yang spesifik dalam menerapkan wasiat wajibah terhadap ahli waris yang berbeda agama. Mereka menganggap bahwa ahli waris yang beda agama dapat menerima pembagian harta dari harta peninggalan pewaris melalui wasiat wajibah sudah menjadi putusan dan pemahaman umum.

Kedua, terdapat kelemahan dalam pertimbangan hakim dalam beberapa putusan tersebut yang mana hakim tidak memisahkan atau tidak membedakan secara prinsip penggunakan konsep "harta peninggalan" dengan "harta warisan". Penggunaan kedua konsep tersebut seringkali diterapkan secara tumpang tindih dan tidak jelas maksudnya,

22 https:/ / putusan3.mabkamahagung.go.id 
sehingga bisa menimbulkan salah penafsiran bagi pencari keadilan atau siapapun yang memahami persoalan tersebut.

Kalau melihat hasil putusan pengadilan baik di Pengadilan Agama, Pengadilan Tinggi Agama, maupun di Mahkamah Agung masih terjadi tumpang tindih penerapan konsep hukum waris (al-Mawaris), harta peninggalan (tirkab), dan harta warisan (al-Irst). Pengadilan kerangkali tidak membedakan dengan tegas perbedaan konsep-konsep hukum tersebut dengan menggunakan konsep yang berbeda untuk suatu pengertian yang sama.

Perbedaan penerapan konsep tersebut dapat dilihat dari beberapa kasus yang terjadi dari mulai putusan Mahkamah Agung RI Nomor 368.K/AG/1995 tahun 1995 tentang kedudukan ahli waris non Muslim yang kemudian diberikan wasiat wajibah dari seluruh harta peninggalan (tirkah) pewaris. Sedangkan pada putusan Mahkamah Agung RI Nomor 51.K/AG/1999 tanggal 29 September 1999, Majelis Hakim mengambil wasiat wajibah dari harta warisan yang sudah akan dibagikan kepada masing-masing ahli waris setelah dikurangi kewajiban-kewajiban hukum si pewaris. Putusan tersebut kemudian dijadikan rujukan sebagai yurisprudensi dalam setiap pengambilan keputusan hukum di tingkat pengadilan, khususnya Pengadilan Agama, Pengadilan Tinggi Agama, serta di Mahkamah Agung RI.

Kalau dikaji secara mendalam istilah warisan berasal dari bahasa Arab Al-Miirats, yang berarti 'berpindahnya sesuatu dari seseorang kepada orang lain'. Sementara harta warisan yang dalam istilah fara'id dinamakan tirkah (peninggalan) adalah semua harta peninggalan si mayit sebelum diambil untuk kepentingan pengurusan mayit, wasiat, atau pelunasan hutang. Sedangkan al-Irst adalah harta yang siap dibagikan kepada ahli waris setelah dikurangi biaya pengurusan mayit, dan lain-lainnya. Berdasarkan kedua konsep tersebut dapat dipahami bahwa pelaksanaan wasiat atau wasiat wajibah seharusnya didahulukan dari pelaksanaan pembagian harta warisan. Hal itu karena bagian wasiat diambil dari harta peninggalan (tirkah).

Sementara itu pula, KHI sendiri membedakan dua konsep, yaitu harta peninggalan dan harta warisan. Menurut KHI pasal 171 huruf d, "harta peninggalan adalah harta yang ditinggalkan oleh pewaris baik berupa harta benda yang dimilikinya maupun hak-haknya. Sedangkan pada pasal yang sama huruf e disebutkan bahwa harta warisan merupakan harta bawaan ditambah bagian dari harta bersama setelah digunakan untuk keperluan pewaris selama sakit sampai dengan meninggalnya, biaya pengurusan jenazah, dan pembayaran hutang seta pemberian untuk kerabat. 
Pemahaman terhadap konsep harta warisan dan harta peninggalan seringkali menimbulkan kesalahpahaman bagi semua orang ketika ingin memahami putusan hakim. Harta warisan sering dipahami sebagai seluruh harta yang ditinggalkan pewaris dan seringkali disamakan dengan harta peninggalan itu sendiri. Dengan demikian penggunaan kedua istilah harus dibedakan agar tidak salah dalam penerapan hukumnya.

Kelemahan dalam penggunaan konsep juga dapat dikaji dari Putusan Mahkamah Agung tentang status ahli waris non muslim yaitu Putusan Mahkamah Agung Nomor: 368 K/AG/1995 tanggal 16 Juli 1995 dan Nomor: 51 K/AG/1999 tanggal 29 September 1999. Dalam putusan nomor $368 \mathrm{~K} / \mathrm{AG} / 1995$ dinyatakan bahwa ahli waris non muslim mendapatkan bagian dari harta peninggalan pewaris muslim berdasarkan wasiat wajibah sebesar bagian ahli waris muslim, dalam putusan ini ahli waris non muslim tidak dinyatakan sebagai ahli waris, dan dalam putusan Nomor $51 \mathrm{~K} / \mathrm{AG} / 1999$ dinyatakan bahwa ahli waris non muslim dinyatakan sebagai ahli waris dari pewaris muslim dan mendapatkan bagian yang sama dengan ahli waris muslim berdasarkan wasiat wajibah, dalam putusan ini dinyatakan bahwa ahli waris non muslim dianggap sebagai ahli waris.

Ketentuan mengenai larangan saling mewarisi antara orang muslim dengan non muslim seolah diabaikan. Penyebutan ahli waris bagi anak yang berbeda agama dengan pewarisnya seolah memberikan pengakuan tentang status hukumnya sebagai ahli waris. Dengan kata lain pengadilan telah memberikan status ahli waris bagi ahli waris non muslim dan memberikan bagian harta yang setara dengan ahli waris muslim.

Kalau mengkaji putusan dan pertimbangan hukum hakim, baik dalam putusan Mahkamah Agung mulai tahun 1995 putusan-putusan hukum baru tahun 2018 menunjukkan penerapan wasiat wajibah dengan statusnya sebagai ahli waris. Hal ini tergambar dari dua putusan awal tentang penerapan wasiat wajibah tersebut dapat memunculkan pertanyaan kenapa dalam putusan nomor $368 \mathrm{~K} / \mathrm{AG} / 1995$ ahli waris non muslim tidak dinyatakan sebagai ahli waris melainkan hanya diberikan harta berdasarkan wasiat wajibah sementara dalam putusan nomor $51 \mathrm{~K} / \mathrm{AG} / 1999$ disamping mendapatkan harta berdasarkan wasiat wajibah ahli waris non muslim juga dinyatakan sebagai ahli waris dari pewaris muslim. Hal tersebut juga menggambarkan adanya disparitas di kalangan hakim mengenai penerapan hukum waris dan wasiat wajibah.

Penetapan statusnya sebagai ahi waris ini tentu bertentangan dengan substansi hukum Islam bahwa ahli waris adalah orang yang memiliki hubungan kekerabatan (nasabiyah) atau perkawinan (sababiyah) serta beragama Islam ketika meninggalnya pewaris. 
Berdasarkan beberapa putusan tersebut jelas pengadilan telah menyimpangi ketentuan hukum, baik pendapat mayoritas ulama maupun ketentuan hukum yang sudah diatur dalam KHI yang secara implisit tidak mengakui ahli waris non muslim sebagai ahli waris dari pewaris muslim. Bahkan KHI di dalam Pasal 171 menjelaskan bahwa ahli waris harus beragama Islam pada saat meninggalnya pewaris sehingga berimplikasi bahwa jika tidak beragama Islam maka tidak dianggap sebagai ahli waris dari pewaris muslim.

Adapun untuk mengidentifikasi seorang ahli waris beragama Islam pasal $172 \mathrm{KHI}$ menjelaskan bahwa ahli waris dipandang beragama Islam diketahui dari kartu identitasnya atau pengakuan atau amalan atau kesaksian, sedangkan untuk bayi yang baru lahir atau anak yang belum dewasa, agamanya menurut ayahnya atau lingkungannya. Dengan demikian, maka anak atau orang yang meskipun memiliki hubungan kekerabatan dan perkawinan namun karena terdapat perbedaan agama maka orang tersebut tidak bisa disebut sebagai ahli waris.

Sementara itu, berdasarkan hasil penelitian kepustakaan dan temuan penelitian empiris melalui teknik wawancara mendalam (dept interview) dengan beberapa Hakim Pengadilan Agama yang berada di wilayah DKI Jakarta tergambar bahwa ada dasar-dasar pertimbangan hakim dalam memutuskan sengketa perkara waris beda dengan memberikan wasiat wajibah. Diantara dasar-dasar hakim, yaitu alasan historis, melakukan interpretasi dan penemuan hukum, alasan keadilan dan menggunakan metode argumentum per analogium.

Pertama, alasan historis yang dijadikan dasar oeh hakim ketika memberikan putusan tersebut adalah bahwa larangan pemberian harta warisan kepada non muslim karena dikhawatirkan merugikan kepentingan umat Islam saat itu dapat diterima. Larangan untuk saling mewarisi tidaklah didasarkan oleh pertimbangan politis saat itu demi kepentingan sesaat melainkan adanya tuntutan maslahatnya hukum yang esensi hukum Islam itu sendiri bahwa memelihara agama (bifdzul al-Din) menjadi salah satu tujuan utama hukum Islam. Selain itu, pemberian harta peninggalan pewaris muslim kepada non muslim yang diterapkan oleh Pengadilan Agama melalui wasiat wajibah tidak bisa dimaknai kebolehan memberikan harta warisan terhadap orang berbeda agama.

Kedua, dalam konteks ini perlu dianalisis bahwa hakim juga memiliki kewenangan untuk menyimpangi ketentuan-ketentuan hukum tertulis yang telah ada yang dianggap tidak lagi kontekstual dengan kehidupan masyarakat yang pluralistik. Dalam konteks Ilmu Hukum cara ini disebut dengan istilah Contra legem dimana hakim harus memberikan pertimbangan-pertimbangan hukumnya secara jelas dengan mempertimbangkan berbagai 
aspek hukum. Putusan hakim tersebut kemudian dijadikan sebagai dasar bagi putusan lain dalam memutuskan kasus hukum serupa yang disebut sebagai yurisprudensi tujuannya untuk menghindari adanya disparitas putusan hakim dalam perkara yang sama.

Penggunaan kewenangan tersebut sejatinya tidak boleh bertentangan dengan prinsip-prinsip hukum Islam yang berbeda dengan prinsip-prinsip hukum Barat. Menurut hukum Islam adanya ketentuan hukum yang sudah pasti berdasarkan dalil hukum yang sudah pasti (qoth'iyyu al-dilalah) dan ada ketentuan hukum yang didasarkan pada dalil yang belum pasti (dhanniyyu al dilalah).

Mengenai dalil hukum yang sudah pasti, tidak ada peluang bagi ulama atau bahkan hakim untuk menginterpretasi dan bahkan menyimpangi ketentuan hukum tersebut, seperti masalah-masalah yang berkaitan masalah ibadah, seperti sholat, zakat, puasa, dan haji. Hukum waris Islam oleh mayoritas ulama dikategorikan bukan masalah ijtihadiyah yang boleh diinterpretasi ulang ketentuan hukumnya. Oleh karena itu, larangan saling mewarisi bagi orang yang berbeda agama adalah bersifat pasti dan dianggap tidak dapat diubah dengan dalih konteks hukumnya berbeda.

Sementara itu, hukum-hukum yang didasarkan pada dalil-dalil yang belum pasti (qoth'iyyu al dilalah) masih memungkinkan atau bahkan sangat memerlukan interpretasi dalam ketentuan dan penerapannya sesuai konteks hukum dimana hukum tersebut akan diterapkan. Hal ini juga selaras dengan kaidah hukum Islam bahwa hukum dapat berubah sesuai dengan perubahan waktu dan tempat dimana keadilan hukum menuntut hal tersebut.

Putusan hakim mengenai penyelesaian sengketa pembagian waris bagi orang yang berbeda agama melalui penerapan wasiat wajibah tidak sepenuhnya dapat dikatakan melakukan upaya penemuan hukum. Jika dikaji secara mendalam, putusan pemberian wasiat wajibah oleh hakim tidak bertentangan dengan pendapat ulama yang membolehkan seorang muslim memberikan wasiat atau wasiat wajibah kepada orang yang berbeda agama. Selain itu, tidak ada ketentuan dalam Al-Quran atau Hadits yang melarang seorang muslim berwasiat orang berbeda agama. Oleh karena itu, berdasarkan kaidah umum fikih bahwa dalam persoalan mualamah berlaku kadaih "segala sesuatu atau perbuatan itu dibolebkan selama tidak ada dalil/dasar bukum yang melarangnya". Dengan demikian berdasarkan kaidah tersebut perbuatan apapun selama tidak bertentangan dengan kaidah-kaidah, asas-asas, atau prinsip-prinsip hukum Islam, maka pelaksanaan wasiat tidak bertentangan dengan hukum Islam. 
Pemberian hak wasiat wajibah kepada ahli waris non-Muslim sebagai alternatif solusi atas kebuntuan hukum sesungguhnya telah memberikan gambaran positif bahwa hukum Islam tidaklah eksklusif yang seolah-olah telah menempatkan warga negara non Muslim lebih rendah kedudukan hukumnya ketimbang mereka yang beragama Islam. Oleh karena itu hukum Islam dapat merespon semua persoalan hukum yang terjadi dengan berbagai konsep hukum yang sudah ada untuk mencairkan kebekuan hukum yang mungkin terjadi.

Hakim sebagai penegak hukum memegang peranan penting dan sentral dalam penerapan hukum. Melalui putusan-putusannya seorang hakim tidak hanya menerapkan hukum yang ada dalam teks undang-undang melainkan hakim harus melakukan pembaruan-pembaruan hukum ketika dihadapkan pada masalah-masalah yang diajukan kepadanya dan belum diatur dalam undang-undang ataupun telah ada aturan tetapi dipandang tidak relevan dengan keadaan dan kondisi yang ada.

Hakim di lingkungan Pengadilan Agama di Indonesia sebagai salah satu penegak hukum Islam ternyata juga telah melaksanakan fungsi menetapkan putusan terhadap perkara-perkara yang diajukan kepadanya dengan terlebih dahulu mengemukakan pertimbangan-pertimbangan hukum pada putusannya tersebut. Melalui putusan tersebut tidak dapat disangkal bahwa ia telah turut berperan dalam pemikiran hukum Islam terlebih lagi ketika putusannya tersebut mengandung pembaruan terhadap pemikiran hukum Islam.

Namun demikian tidak semua hakim mau menggunakan interpretasi dalam melakukan penemuan hukum. Kebanyakan hakim lebih berorientasi kepada undangundang, dan kurang adanya upaya untuk menggali nilai-nilai hukum, termasuk kaidahkaidah, prinsip-prinsip, dan asas-asas hukum yang ada dalam hukum Islam yang bisa digunakan untuk memecahkan masalah-masalah hukum baru di masyarakat. Sejatinya hakim tidak lebih mengutamakan yuridis formil dalam penegakan hukum pada perkaraperkara perdata. Pengutamaan aturan formil yang terikat prosedur dan tata cara yang baku dalam hukum acara perdata kadang-kadang menyebabkan hakim kehilangan fungsi sebagai penggali hukum yang hidup di masyarakat.

Putusan hakim yang menolak pemberian harta warisan bagi orang yang berbeda agama di lingkungan Pengadilan Agama sebelum putusan Pengadilan Tinggi Agama Jakarta dan putusan MA tahun 1995 semata-mata mempertimbangkan dasar yuridis normatif hukum Islam yang mengatur larangan saling mewarisi orang yang berbeda agama. Hakim dalam menangani kasus tersebut tidak mencoba mencari instrumen hukum 
lain dalam hukum Islam yang bisa digunakan oleh kalangan hakim untuk menyelesaikan masalah hukum waris beda agama. Hakim dalam hal ini bersikap pasif sesuai prinsip umum dalam memeriksa perkara perdata yang diajukan ke Pengadilan sesuai dengan gugatan yang diajukan oleh para pihak yang berperkara.

Selain itu, besaran perolehan harta melalui wasiat wajibah cenderung menggunakan batas maksimal perolehan harta berdasarkan batas maksimal wasiat. Meskipun ada juga yang berbeda dalam pengambilan batas maksimal perolehan harta melalui wasiat wajibah. Dalam putusan pengadilan misalnya dinyatakan bahwa ahli waris non muslim mendapatkan bagian dari harta peninggalan pewaris muslim berdasarkan wasiat wajibah sebesar bagian ahli waris muslim. Sementara dalam putusan lain ahli waris non muslim tidak dinyatakan sebagai ahli waris, tetapi diberikan bagian yang sama dengan ahli waris muslim berdasarkan wasiat wajibah.

Meskipun pertimbangan setiap hakim dapat berbeda-beda mengenai besaran wasiat wajibah dalam setiap kasus, namun terdapat suatu asas yang menjadi dasar dalam menjatuhkan besaran wasiat wajibah, yaitu asas keseimbangan. Wasiat wajibah diberikan tidak mengganggu kedudukan ahli waris lainnya. Bagian harta peninggalan yang diperuntukan untuk wasiat wajibah diberikan dari derajat yang sama. Anak perempuan tidak beragama Islam mendapat bagian yang sama sebesar bagiannya dengan kedudukannya sebagai anak perempuan. Begitu juga dengan kedudukan isteri yang tidak beragama Islam, akan mendapatkan bagian yang sama besar bagianya dengan kedudukannya sebagai isteri seperti Mahkamah Agung No. 16 K/AG/2010.

Putusan-putusan tersebut dterbitkan oleh karena terjadi pergesekan kepentingan antar ahli waris. Ahli waris akan menikmati bagian secara kualitatif yang lebih sedikit dengan adanya lembaga wasiat wajibah. Bagian para ahli waris yang sudah ditentukan, dialihkan kepada penerima wasiat wajibah oleh karena ijtihad hakim yang berwenang. Tuntutan-tuntutan para ahli waris adalah menyampingkan lembaga wasiat wajibah.

Sekilas putusan-putusan tersebut di atas tidak didasarkan pada hukum Islam atau menyimpangi ketentuan normatif hukum dari Al-Quran dan Hadits. Putusan-putusan tersebut diterbitkan untuk memenuhi asas keadilan bagi para ahli waris yang memiliki hubungan keturunan atau perkawinan dengan pewaris. Hakim menjamin keadilan bagi orang-orang yang memiliki hubungan emosional dengan pewaris tersebut melalui lembaga wasiat wajibah. Seorang anak ataupun anak yang berbeda agama dan telah hidup berdampingan dengan tentram dan damai serta tingkat toleransi yang tinggi dengan 
pewaris yang beragama Islam tidak boleh dirusak oleh karena pewarisan. Penyimpangan yang dilakukan akan memberikan lebih banyak kemaslahatan daripada mudarat.

Sifat dari ijtihad yang dilakukan hakim tdak bersifat impertif akan tetapi fakultatif. Penggunaan putusan-putusan tersebut apabila terjadi sengketa dan sebaliknya apabila tidak terjadi sengketa maka tetap menerapkan hukum Islam sebagaimana atauran normatif. Dengan demikian, hukum Islam tetap berlaku sesuai prinsip-prinsip, asas-asas, dan kaidah-kaidah hukum sebagaimana termaktub dalam sumber asasi, yaitu Alqur'an, hadits, dan ijtihad ulama.

\section{KESIMPULAN}

Ketentuan pembagian waris terhadap orang berbeda agama tidak diatur secara eksplisit dijelaskan di dalam Alqur'an melainkan hanya menggunakan rumusan umum dalam surat An-Nisa ayat 141 yang menentukan tidak memberikan jalan kepada orang-orang non Islam. Ketentuan normatif ditegaskan secara jelas di dalam teks Hadits yang diriawayatkan Usamah bin Zaid yang menyatakan bahwa; "Orang Muslim tidak (boleh) mewarisi orang non Islam, dan orang non Islam tidak (boleb) mewarisi orang Muslim". Atas dasar landasan itu pula para ulama fiqih mau ulama tafsir berpendapat bahwa perbedaan agama menjadi salah satu penghalang untuk mewarisi antara pewaris dengan ahli waris. Namun demikian, para ulama membolehkan pewaris memberikan wasiat kepada kerabat dekat (aqrabin) yang tidak mendapatkan hak waris. Selaras dengan pendapat tersebut, Majelis Ulama Indonesia melalui Fatwa Majelis Ulama Indonesia (MUI) hasil MUNAS Nomor: 5/MUNAS VII/MUI/9/2005 menegaskan bahwa ketentuan bahwa orang yang berbeda agama tidak dapat saling mewarisi bersifat mutlak (qath'i) dan tidak dapat diinterpretasi ulang sesuai konteks perubahan kehidupan masyarakat sampai kapanpun. Oleh karena itu, alternatif solusi yang bisa ditempuh untuk menyelesaikan masalah tersebut yaitu melalui pemberian hadiah, hibah, atau wasiat. Meskipun Kompilasi Hukum Islam (KHI) dalam pasal 209 hanya mengintrodusir wasiat wajibah dalam rangka mengatur untuk anak angkat dan orang tua angkat, tetapi berdasarkan ketentuan dalam Alqur'an, Hadits, dan pendapat para ulama memungkinkan implementasi wasiat wajibah dalam menyelesaikan sengketa waris beda agama.

Dasar-dasar pertimbangan hukum yang dijadikan landasan berfikir hakim yang digunakan tidak terlepas dari beberapa alasan hukum, yaitu historis, alasan adanya kemaslahatan dan keadilan, interpretasi hukum dalam rangka penemuan hukum (rechtsvinding), metode argumentum per analogium atau analogi hukum, dan menjadikan hukum 
waris Islam menjadi bagian dari sistem kewarisan nasional. Penggunanan alasan tersebut tidak seluruhnya dapat diterima dengan logika hukum Islam, mengingat hukum Islam memiliki konsep, dasar, prinsip, dan metodenya sendiri dalam merumuskan hukum yang tentu berbeda dengan hukum Adat atau hukum Perdata Barat. Penerapan wasiat wajibah sebagai solusi penyelesaian sengketa pembagian waris bagi orang yang berbeda agama masih menyisakan problem dalam menerapkan konsep-konsep hukum Islam yang benar. Bagian wasiat wajibah sebagaimana wasiat biasa seharusnya diambil dari harta peninggalan pewaris sebelum adanya pembagian harta warisan dengan jumlah yang bisa bervariasi tergantung nilai keadilan pada setiap kasus yang dihadapi. Kedudukan ahli waris yang beragama non Islam tidak dapat diposisikan sebagai ahli waris, melainkan sebagai kerabat dekat yang tidak mendapatkan bagian harta warisan. Sebagai kerabat dekat, ahli waris yang beragama non Islam dapat memperoleh harta melalui hibah atau wasiat sebelum pewaris meninggal. Jika belum terlaksana, maka penerapan wasiat wajibah dapat diterapkan setelah pewaris meninggal.

\section{SARAN}

Perlunya rekonstruksi hukum perdata Islam dalam rangka merespon dinamika perubahan hukum baru di masyarakat, khususnya masalah-masalah hukum perdata Islam yang berlaku di Indonesia dengan melibatkan berbagai stakeholders diantara para ulama (MUI), hakim, akademisi, dan praktisi hukum Islam. Upaya tersebut diharapkan dapat memberikan masukan untuk reformulasi rumusan dalam ketentuan-ketentuan hukum yang diatur di dalam Kompilasi Hukum Islam (KHI). Selanjutnya dengan itu diharapkan KHI dapat ditingkatkan menjadi undang-undang agar memiliki kekuatan normatif dalam mengatur ketentuan hukum di masyarakat, khususnya golongan masyarakat yang beragama Islam yang menjadi objek penyelesaian sengketa di lingkungan Pengadilan Agama.

Perlunya para hakim melakukan kajian bersama mengenai persoalan-persoalan hukum baru kontemporer, khususnya yang terkait dengan hukum perdata Islam yang berlaku di lingkungan Pengadilan Agama untuk memaksimalkan tugas hakim yang tidak lagi hanya menjadi corong undang-undang tetapi juga mampu melakukan penemuan hukum tanpa tercerabut dari akar ketentuan normatif hukum Islam itu sendiri. 


\section{DAFTAR PUSTAKA}

\section{A. Buku-buku}

Dahlan, Abdul Aziz (ed), Ensiklopedi Hukum Islam, Jakarta: PT. Ichtiar Baru van Hoeve, 1996

Hazm, Ibn, Al-Muhalla, juz X, al-Qahirah: Maktabah al-Jumhuriyyah al-Arabiyyah, 1970

Hidayati, Sri, Ketentuan Wasiat Wajibah di Pelbagai Negara Muslim Kontemporer. Jakarta: Jurnal Ahkam, Vol.XII, No.1, Januari 2012

Juzairi, al-, Syaikh Abdurrahman, Kitabul Fighi Ala al-Madzabib al-Arbaah, Beirut: Daar alDayyan Li al-Turats, juz III,

Manan, Abdul, Beberapa Masalah Hukum tentang Wasiat dan Permasalabannya dalam Konteks Kewenangan Peradilan Agama", Mimbar Hukum Aktualisasi Hukum Islam Nomor 38, Vol. IX, 1998.

Nugraheni, Destri Budi dkk, Pengaturan dan Implementasi Wasiat Wajibah di Indonesia, Jurnal Mimbar Hukum, Volume 22, Nomor 2, Juni 2010

Qudamah, Ibn, Al-Mughni, Beirut: Dar' al-Kitab Al-Ilmiyyah, tth, Juz. VI

Rusyd, Ibnu, Bidayatul Mujtahid, Juz 2, Semarang: Usaha Keluarga, tt.

Sabiq, Sayid, Fiqh Al Sunnah, juz 3, Kairo: Maktabah Dar al Turast, tt.

Shiddiqy, Ash-, TM. Hasbi, Fiqih Mawaris, Semarang: PT. Pustaka Rizki Putra, 1999

Turmudzi, Al-, Sunan Al-Turmudzi, Beyrut: Daar al-Fikr, 1980, Juz II.

Zuhaily, al, Wahbah, Fiqh al-Islam Wa Adillatubu, Damaskus: Dar Al Fikr, 1996

\section{B. Peraturan Perundang-undangan}

Republik Indonesia, Instruksi Presiden Nomor 1 Tahun 1991 tentang Kompilasi Hukum Islam

Putusan Mahkamah Agung Nomor: 368 K/AG/1995

Putusan Mahkamah Agung Nomor: 51 K/AG/1999

Putusan Pengadilan Tinggi Manado Nomor : 01/Pdt.G/2007/PTA.Mdo

Putusan Pengadilan Tinggi Agama Surabaya Nomor: 18/Pdt.G/2007/PTA.Sby.

Putusan Pengadilan Agama Surabaya Nomor: 473/Pdt.P/2010/PA.Sby.

Putusan Pengadilan Agama Kabanjahe Nomor : 2/Pdt .G/2011/PA- Kbj

Putusan Pengadilan Tinggi Agama Surabaya Nomor: 459/Pdt.G/2013/PTA.Sby.

Putusan Pengadilan Tinggi Agama Makassar Nomor 43/Pdt.G/2014/PTA.Mks

Putusan Pengadilan Tinggi Agama Pelambang Nomor 05/Pdt.G/2015/PTA.Plbg

Putusan Pengadilan Tinggi Agama Banten Nomor 78/Pdt.G/2017/PTA.Btn

\section{Sumber lain}


KRTHA BHAYANGKARA | Volume 15 Number 1, June 2021

Baihaki, Ahmad, Penerapan Wasiat Wajibah dalam Penyelesaian Sengketa Pembagian Waris Beda Agama di Lingkungan Pengadilan Agama DKI Jakarta, Laporan penelitian hukum, Jakarta: FH-Ubhara Jaya, 2015

https://putusan3.mahkamahagung.go.id/direktori.html

https:/ / putusan3.mabkamahagung.go.id 